Article

\title{
Environmental Upgrading and Suppliers' Agency in the Leather Global Value Chain
}

\author{
Valentina De Marchi *(D) and Eleonora Di Maria \\ Department of Economics and Management 'Marco Fanno', University of Padova, 35123 Padova, Italy; \\ eleonora.dimaria@unipd.it \\ * Correspondence: valentina.demarchi@unipd.it; Tel.: +39-049-8273782
}

Received: 30 October 2019; Accepted: 15 November 2019; Published: 20 November 2019

\begin{abstract}
The paper explores the role of suppliers in the process of environmental upgrading (EnvU) within global value chains (GVCs). Theoretical contributions to EnvU have highlighted, in particular, the role of global buyers in supporting the EnvU of products and processes, while limited attention has been given to suppliers as proactive actors within GVCs. This paper approaches EnvU through the lens of innovation and focuses on the agency of suppliers. Through the analysis of innovations developed within the leather GVC, with a special focus on the Arzignano cluster (Italy), the analysis shows how suppliers can autonomously develop sustainability strategies to maintain their competitiveness and achieve higher value in the GVC. However, results stress the limits of green strategies as buyers and suppliers do not share the same vision of how to foster sustainability.
\end{abstract}

Keywords: environmental upgrading; innovation; leather; supplier; sustainability, circular economy

\section{Introduction}

An increasing number of firms are developing strategies to achieve positive environmental outcomes or reduce the environmental damages of their business activities due to internal or external drivers [1]. Due to the fragmentation of economic activities among a large number of actors, environmental sustainability cannot be achieved by a single firm alone: the interdependency between the different steps of the value chain has to be taken into account [2,3]. From this point of view, the buyer-supplier relationship is a relevant perspective to investigate the sustainability strategies of firms.

Within the literature on global value chains (GVCs), sustainability strategies have been explored through the concept of environmental upgrading (EnvU) [4]. According to GVC scholars, firms can upgrade their product or process or improve their organization account for the environmental consequences of their business [5]. In particular, GVC studies have explored the role of lead firms in pushing the greening of the entire value chain and the implications from a governance point of view [6]. Minor attention has been given to suppliers and their role in promoting EnvU [5,7]. However, recent studies on the upgrading of suppliers within the GVC show that suppliers can rely on their internal capabilities to improve their product and processes, and are not necessarily supported by lead firms [8-10].

Further knowledge is required to understand whether and how suppliers can contribute to EnvU in the value chain through their strategies. From this perspective, the goal is to explore the autonomous capacity of suppliers to adopt and promote sustainability strategies by considering EnvU as part of an innovation process. This is particularly relevant considering the recent literature suggesting limitations in the role of lead firms in EnvU. Specifically, scholars indicate that standard definitions and codes of conduct set by lead firms might not be enough to ensure the greening of their value chain. In fact, actors along the chain (i.e., suppliers, farmers) might resist the change (e.g., by pretending to implement greening initiatives), might require negotiations of greening requests, or might adapt 
initiatives depending on their own cost structure and incentives, which might have an important impact on the effectiveness of the lead firms' strategies [11,12].

This paper responds to this research question by taking into account the GVC framework as well as the theoretical contributions from the environmental innovation literature $[13,14]$ and by investigating the leather GVC as one of the highest polluting industries worldwide.

\section{Environmental Upgrading and Sustainability Strategies: Exploring the Role of Suppliers}

\subsection{Environmental Upgrading in Global Value Chains}

The global value chain framework describes the global economy as consisting of a "complex and dynamic economic network made up of inter-firm and intra-firm relationship[s]" [13], and has been widely adopted as a framework to understand the internationalization of industries given its ability to understand developmental trajectories of industries, accounting for the role of key actors (namely global lead firms) and other actors that populate the chain [14]. Starting with the analysis of detailed input-output structures, which depict the value-added activities of the chain and the geographies of the actors involved, the literature analyzes the opportunities for firms to realize more such activities and appropriate the value generated thanks to the engagement in the GVC driven by lead firms, i.e., to upgrade [15]. While the majority of the literature focuses on economic upgrades, it has recently pivoted to include the analysis of EnvU as well $[5,16]$.

Environmental upgrading can be defined as "the process by which economic actors move towards a production system that avoids or reduces environmental damage from their products, processes or managerial systems" [17]. A more complete definition is provided by Krishnan (2017, p. 117), which suggests it regards positive (or reduction in negative) environmental outcomes as a result, highlighting the fact that such improvements at the firm level have the potential to provide positive results rather than just offsetting negative ones. Indeed the focus on outcomes is a key aspect of EnvU, which is usually overlooked in the empirical literature [5], which focuses on the motivations of the greening. The measurement of such (direct and indirect) outcomes is a challenging yet essential element to consider $[7,18]$.

According to De Marchi et al. (2019), different typologies of EnvU can be implemented by economic actors, depending on if they affect how the products are realized (process EnvU), how the product portfolio that is offered (product EnvU), or the overall way in which the firm is managed and profits are realized (organizational EnvU). Attention to process improvement means investing in technology or process redesign to reduce environmental damage and increase efficiency from an environmental point of view. A more complex, additional layer to eco-efficiency is the firm's investment in a product, where the goal is to expand the firm's offering to include products that are more environmentally-friendly [19]. On the one hand, the firm can transform existing products, taking more sustainable inputs, an extended product life cycle, or reduced impacts during product use into account. On the other hand, new products can be launched, which embedded the environmental perspective since its inception, being a dominant perspective in the product innovation process and not as a secondary step with respect to other drivers (i.e., product functionality) [20]. Finally, organizational improvement implies the improvement of organizational processes, and managerial practices consider the need to cope with environmental pressures and requirements, for example via the adoption or development of standards. Under this perspective, it is clear that EnvU overcomes the manufacturing domain to include any business activity and behavior that can reduce impacts on the environment [21,22].

From this point of view, EnvU can be conceived as an innovation process, where new technical or organizational knowledge is produced or applied by a firm in order to achieve environmental goals. A peculiarity of the innovation process that entails environmental outcomes is the fact that a stronger collaboration with the actors of the value chains is needed in order to achieve environmentally-related improvement $[2,23]$. On the one hand, the firm relies on external partners for collaboration related to sustainability [3], but, on the other hand, it is also important to consider the firm's internal capabilities 
in terms of absorptive capacity [24,25]. While diverse external partners might be important for firms to go green, the role of suppliers has been investigated the most, as suppliers contribute to the materiality of the product directly and might be essential in identifying new solutions to reduce impacts $[6,26]$.

\subsection{Drivers of Environmental Upgrading}

The rationale for firms to go green may be diverse. According to [1], there are external and internal drivers of corporate sustainability. External drivers are linked market demand, stakeholders' requests, the need to cope with external regulation, the opportunity for collaboration with value chain partners, and the institutional context in which firms are embedded. These drivers help the firm invest in sustainability but might be weaker motivations as compared to internal drivers, creating a more reactive approach. On the contrary, internal drivers are linked to proactive leadership, corporate cultures and values, reputation, and new market opportunities (market-driving). A more holistic analysis suggests considering these simultaneously and in a complementary way.

A similar approach towards sustainability drivers is followed by studies on environmental innovation, which have identified three main drivers for firms to invest in such a strategic direction [27]: technology, regulation, and market. The first driver refers to technological innovation (technology-push): new technological solutions for process improvement or product production and new materials allow firms to improve their environmental impacts. The emergence of new technological tools, such as blockchain [28], could further enable resource and product traceability. Indeed, technologies related to the fourth industrial revolution and digitalization of manufacturing processes open relevant and important opportunities for firms to achieve environmental sustainability goals e.g., [29].

The second driver is regulation. The government may approve stronger norms in order to push firms to adopt processes and products that are safer for the environment. In addition to market pressure, regulation can also positively influence firms' investments in sustainability by the adoption of market-based mechanisms [30].

The third driver is the market and the consumers' pressure on firms to produce more sustainable products (market pull). The increasing demand for greener products opens new market opportunities for firms that can modify their current offering or develop new, greener products. Conscious customers ask for products that have lower environmental impacts and include environmental-related attributes of the products within their broader consumer purchasing process [31]. In the context of GVCs other than, or in addition to, final customers, lead firms are a powerful market driver, especially in the case of suppliers from developing countries. Lead firms define more sustainable requirements which they require suppliers to adopt through alternative forms of governance [6,32]. By emphasizing the buyer-driven perspective, GVC literature suggests that the sustainability strategies of lead firms impact the whole value chain because of the definition of standards and product and process requirements of suppliers [33].

\subsection{Environmental Upgrading and Suppliers' Agency}

Within the GVC literature, the concept of upgrading maintains that suppliers can "move up" in the chain by increasing the value achieved [34]. Depending on the types of governance implemented by the lead firms of the chain-market, modular, relational, captive, or hierarchy—and the related power distribution, either the lead firm or the supplier can be the source of knowledge for improvement. In captive forms of governance-largely explored by GVC studies, especially with a focus on developing countries-the lead firm is the driver for upgrading, transferring knowledge, and sustaining the capability growth of suppliers, while suppliers may have more limited managerial capabilities to address upgrading autonomously [35]. Where the other forms of governance are concerned, suppliers may demonstrate the capability to enhance their product or processes or even to enlarge their competences by investing in new functions (i.e., design or brand, functional upgrading).

As mentioned before, in the case of EnvU, scholars have identified different mechanisms—standarddriven and mentor-driven - that the lead firm can apply in order to support the shift of its suppliers 
towards sustainability [6]. However, suppliers have their own autonomous strategy, as suggested by [8]. This has to be taken into account when analyzing the upgrading processes, where suppliers can profit from upgrading through defined appropriability regimes, according to their capabilities and assets. Similarly, suppliers may also adopt a proactive approach to modify their products or processes for sustainability purposes, where the strategic direction is defined by the same supplier and not necessarily driven by the lead firm.

The emergence of large first-tier suppliers in emerging countries (i.e., the well-known case of Foxconn) is a clear example of the role of suppliers [36,37]. The role of suppliers' agency, however, has so far been studied in the context of economic upgrading, while little is known about EnvU. Such a research gap is particularly important, given the role that suppliers have in ensuring the greening of industries, which has been detailed in the previous section. Accordingly, in this paper, we address the following research questions: To what extent can suppliers autonomously pursue EnvU processes? What are the motivations for firms to pursue environmental upgrades in GVCs?

\section{Methodology and Empirical Setting}

In order to provide a better understanding of EnvU in GVCs with special attention to the role of suppliers, we performed an in-depth, qualitative analysis within the leather GVC, which we believe represents an ideal context in which to explore the EnvU dynamics. The leather industry is one of the highest polluting industries [38], and its products supply many downstream industries that are also high polluters, such as the fashion and automotive industries. The investment in environmental sustainability has become a priority in recent years. Many lead firms in the output industries have developed strategies and standards to enhance sustainability within the leather GVC [39,40].

Considering the exploratory and complex nature of the research question, we adopted a case study approach, selecting the development of a specific innovation as the focus of the analysis, which involved several actors along the value chain and addresses one of the most relevant environmental concerns in the chain: the use of chemicals in the tanning process and its implication for the end of life of products realized using this material. Such complex innovations have been developed within the LIFE project of the European Commission (GreenLIFE: Green Leather Industry for the Environment, LIFE13 ENV/IT/000840, www.greenlifeproject.eu). Half the funding for GreenLIFE was provided by the European Union (EU), and the project lasted from 2014 to 2017. The project aimed to develop a more sustainable leather manufacturing process through technological and process innovation and engaged five companies based in the Arzignano tannery district, one of the largest tannery areas in the EU: Dani, Gruppo Mastrotto, Ikem, Ilsa, and Acque del Chiampo.

\subsection{The Empirical Context}

The Arzignano tannery district, located in Italy, is a fit setting in several respects. According to FAO data [41], Italy is the fifth producer of leather worldwide, the first exporter for values, and the second for quantity in terms of leather from both bovines and from sheep and goats. According to UNIC data [42], in 2015, Italy represented 19\% of the production value worldwide (5.2 billion euros) and $25 \%$ of the global export of finished leather, making Italy the largest leather producer in EU. Italy host $78 \%$ of EU companies (1243 firms) and $52 \%$ of the employees $(17,824)$ specialized in this industry. Furthermore, it represents $65 \%$ of the EU production value and exported $70 \%$ of EnvU finished leather exports. In this context, the Arzignano district is responsible for $54 \%$ of the overall Italian production, being mainly oriented toward production for the automotive industry and, to a lesser extent, the fashion industry (UNIC 2015).

The high degree of agglomeration of economic activities within the Arzignano cluster generates a high concentration of impacts for the local community and environment. Natural capital (water availability and tannins in the area) and social capital (knowledge of the tanning process) are at the origin of the Arzignano cluster [43,44]. The industrial cluster emerged in the 1950s, based on traditional artisanal experience and knowledge of the chemical tanning process, It rapidly developed 
in the 1960s and 1970s thanks to the flexibility of SMEs established in the area and the ability of the network of firms to deliver high volumes of tanned leather in a short time. It was also in those years that mechanical and chemical players in the tanning industry started to develop. A high level of international business integration, the increasing competition of emerging countries, the aging and fragmentation of demand, and increasingly stringent environmental legislation have been the reference elements of the competitive environment since the 1980s.

Since the early 1970s, in response to these pressures, the cluster has undertaken intense activity in EnvU, acting both at the cluster level and the firm level, with a gradually more systemic approach. A consortium comprising a network of tannery businesses, with the support of local administrations, built a water treatment plant (named Acque del Chiampo, and located within the district) and an industrial sewage system for all the tannery firms located in the cluster area to collect sludge and water refuse from the tanneries. These investments represent a baseline infrastructure for the improvement of the local environmental situation and the foundation for further cluster development (water management, in particular, influences the growth of tannery activities in the area). This shared and collectively managed infrastructure is one of the most important environmental, economic, and social responses to environmental pressure and stringent regulation. This specific investment represents a unicum in the tannery industry at the international level and suggests the orientation of local actors towards sustainability [45], making an interesting setting for the analysis.

\subsection{Data Sources}

The analysis takes into account the variety of actors characterizing the cluster and the value chain in which leather production takes place. It is based on the triangulation of evidence emerging from different data sources, which is a proven approach to improve the quality of research and its reliability by cross-validating the information collected [46].

The primary source for the analysis was interviews with key informants within the firms that participated in the project. Within each of the companies, we interviewed

- Technicians who led the development of new technologies (being the R\&D managers), asking about the technical details of the project and the expected economic and social implications of their introduction,

- The CEO of the firms involved to understand the drivers of the introduction of the technologies, their role within the broader strategy of growth of the companies, and potential bottlenecks that might hinder the diffusion of technologies.

Additionally, we interviewed key informants who belonged to firms that did not participate in the project but who belong to the same GVCs and could provide precious contextual information to understand challenges and drivers of the new technologies to be diffused in the industry so as to validate the economic and social elements collected in the previous interviews. To the same purpose, we also interviewed representatives of other local tannery companies (leather district representatives) and local institutions (the majors of cities where the largest number of Arzignano cluster tanneries located, therefore, where the highest social costs for tannery production are concentrated).

In total, we performed 18 interviews, which took place between January and April 2017, as the new technologies were already almost at their definitive stage, and the actors had clearer ideas about what the potential costs might be. An overview of the interviews performed is reported in Table 1. 
Table 1. The interviews performed.

\begin{tabular}{cccc}
\hline \multirow{2}{*}{ Sector } & Company/Institution & Number of Interviews & Role of Interviewees \\
\hline \multirow{2}{*}{ Tanning industry } & Dani & 3 & Technicians \\
& Gruppo Mastrotto & 1 & CEO \\
\cline { 2 - 4 } & \multirow{2}{*}{ IKEM } & 2 & Technicians \\
& 1 & CEO \\
\hline \multirow{2}{*}{ Chemicals } & Ilsa & 1 & Technician \\
& & 1 & CEO \\
\hline Depuration & Acque del Chiampo & 1 & Technician \\
Chemicals & Corichem & 1 & CEO \\
Machineries & Erretre & 1 & Technicians \\
\hline \multirow{2}{*}{ Municipality } & Arzignano & 1 & Technician \\
Leather district & Chiampo & 1 & Technician \\
\hline
\end{tabular}

Other sources were used to triangulate the emergent analysis:

- Documentary information, including project documents, corporate documents, and industry reports. All the projects documents, including the LCA analysis performed as part of the project, can be accessed at https://www.greenlifeproject.eu/. In particular, industry reports were particularly useful in quantifying leather value chain publications by the following institutions:

- Italian Leather Association (UNIC—Unione Nazionale Industria Conciaria) [42,47]

- Food and Agriculture Organization of the United Nations (FAO) [41]

- The European Leather Association (COTANCE-Confederation of National Associations of Tanners and Dressers of the European Community) [48]

- Participation in public events of the GreenLIFE project, where, other than technicians and CEO of the partners, representatives of the industry and local institutions have commented on the results of the projects.

- Direct observation: all interviews have been conducted at firms' facilities to enable a deeper understanding of the technology developed and provide additional information on the companies interviewed.

\section{Results}

\subsection{The Leather Global Value Chain: Input-Output Structure and the Actors Involved}

In order to grasp the EnvU opportunities in the leather value chain and following the GVC methodology, the first step of the analysis was to map the activities and the actors that made up the chain [49]. Figure 1 reports a simplified version of the input/output structure that we developed, describing the typology of companies involved in each value chain segment. For the sake of this analysis, in the next section, we focus mostly on leather production (the key suppliers in the context of this analysis) and on firms using leather to manufacture their final products (the buyers, often lead firms).

\subsubsection{Hides and Skins}

Initial actors in the chain are farms that produce different types of animals for meat production. The hides and skins of the animals are a by-product that is sold to tanneries directly by (large) slaughter-houses (in some cases, independent firms, in others, vertically integrated farms), importers, 
or other types of intermediaries that pool hides and skins from different (small) slaughter-houses or farms to be sold in international markets. According to UNIC (2015) data, hides and skins represent, on average, $56 \%$ of the total costs of tannery production in Italian companies. Sourcing skins of the needed quality is a key function for companies.

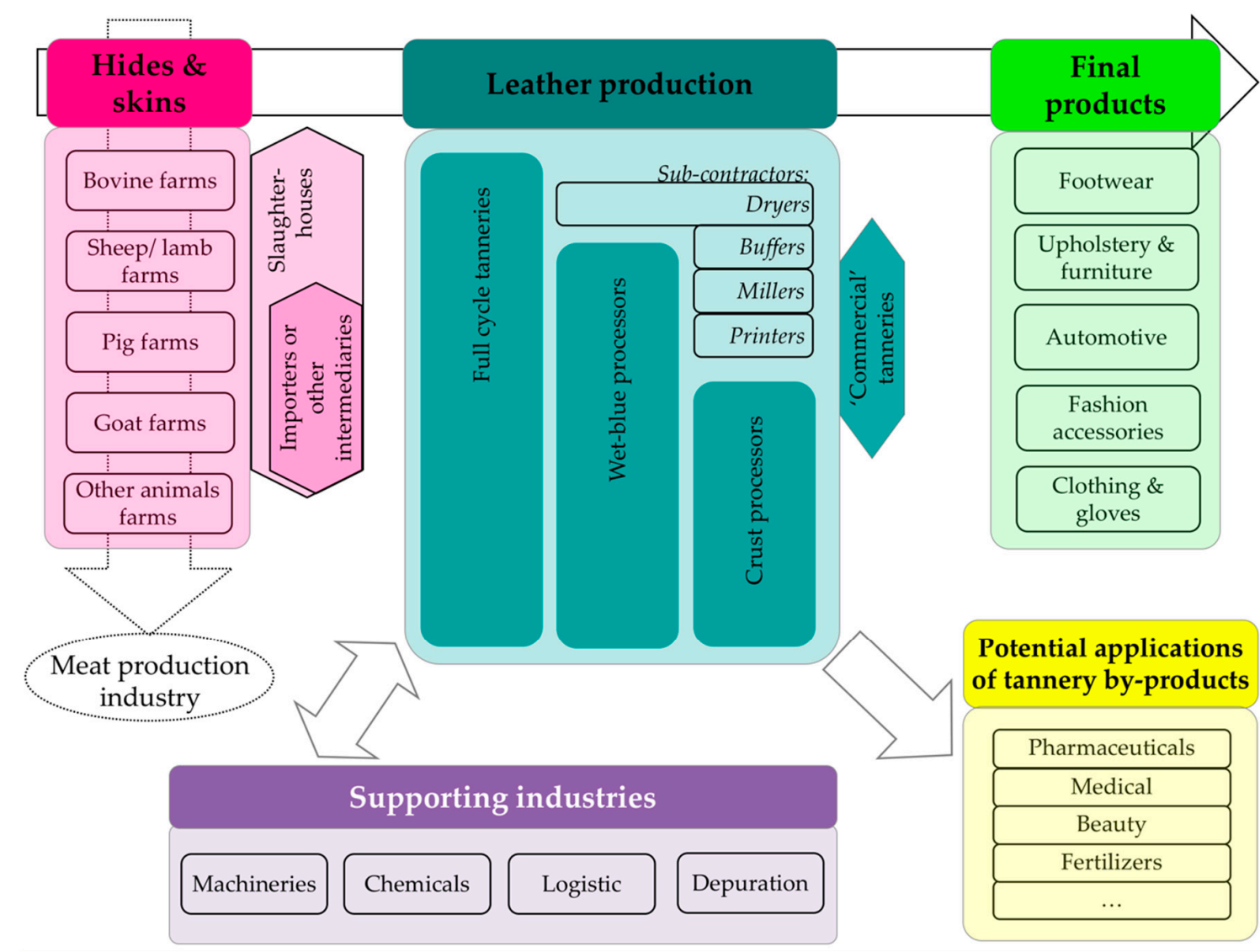

Figure 1. The leather global value chain. Source: authors' elaboration.

\subsubsection{Finished Leather Production}

The leather production process consist of different stages, illustrated in the center of Figure 2, which start with raw hides (either fresh raw hides coming to nearby sources or salted rawhides) and ends with the realization of leather, which might be cut according to the shape defined by a client by tannery companies, by specialized companies, or by the clients themselves. Production costs represent about $10 \%$ of the total costs of tanneries. In the context of our analysis, such firms represent the suppliers.

Different types of tanneries can be identified based on how many activities (of those listed in Figure 2) they carry out internally, i.e., based on their degree of vertical specialization. In the context of this study, companies that realize all the manufacturing steps are named "full-cycle" tanneries, being vertically integrated, they are usually the largest companies. Other tanneries are more specialized in the processing of wet blue or wet white leather, i.e., they are involved in the re-tanning, drying, and finishing steps but not in the liming and tanning steps. We refer to these partial-cycle tanneries as "wet-blue processors".

The third group of companies process the outcome of the tanning and re-tanning process-the crust leather-focusing on the finishing activities. We refer to these companies as "crust processors."

Finally, it is important to mention that in the context of high division of labor, such as the Arzignano cluster where the GreenLIFE project has been developed, companies that specialize in just in few stages 
exist, which might work as capacity suppliers or as specialized suppliers (named "sub-contractors") for any of the three types of tanneries described above.

Figure 2 presents the four types of actors, grouping the activities they perform. Such a classification of tanneries is particularly important to the aim of this article, as the new processes developed within the GreenLIFE project only involve the initial activities and could, therefore, be applied to full-cycle tanneries and liming and tanning sub-contractors.

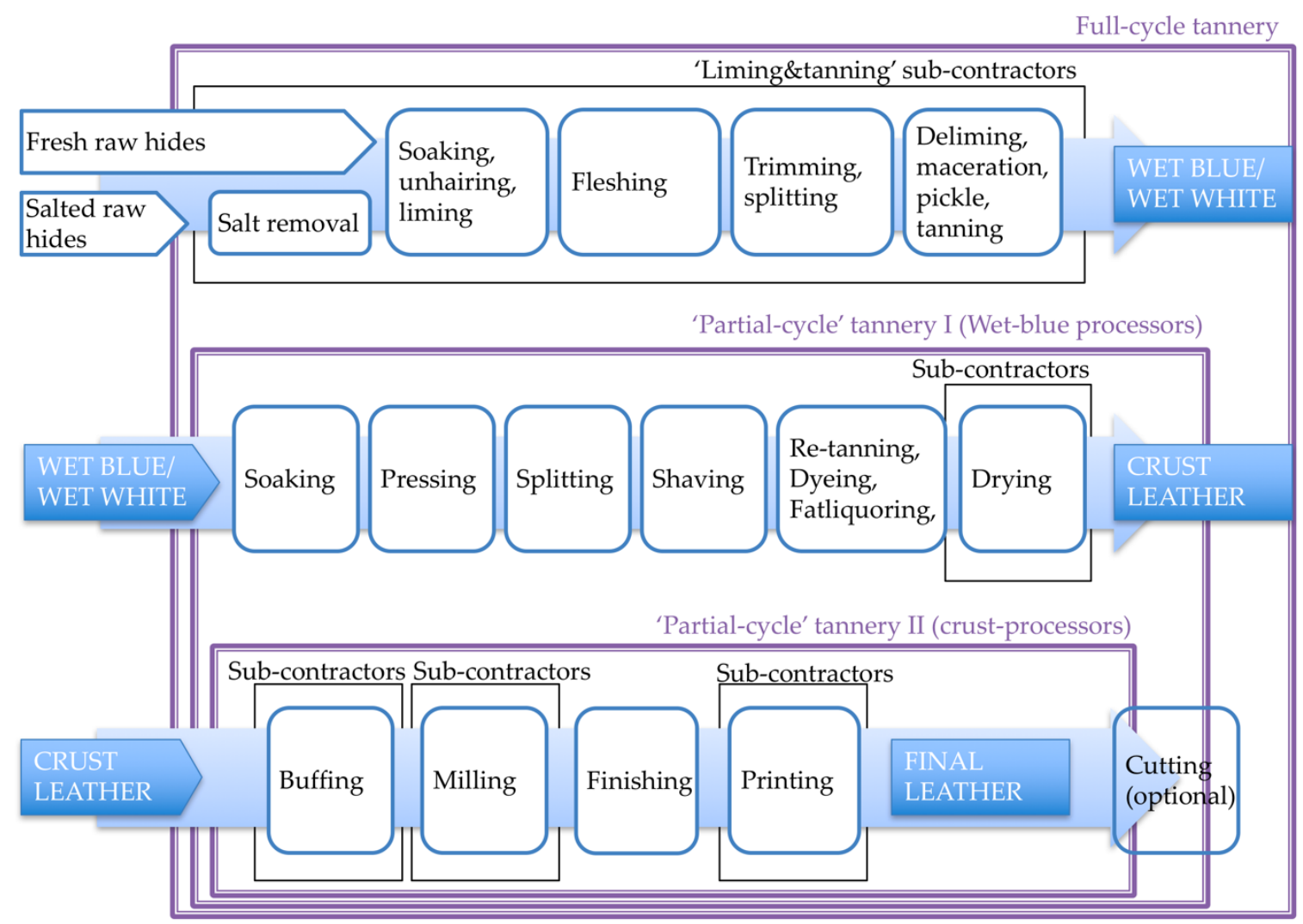

Figure 2. The leather production process and the firms performing each activity. Source: authors' elaboration.

\subsubsection{Final Products Using Leather as an Input}

Leather represents the input for a diversified set of companies specialized in different industries. UNIDO data [50] reports that, as of 2010, industries using the largest quantitates of finished leather in production are footwear $(53.5 \%)$, upholstery and furniture $(13.5 \%)$, clothing $(11.4 \%)$, and leather goods (9.1\%) (Figure 3). While still the dominant industry using finished leather, the footwear industry's use of leather has slightly decreased (from $67.9 \%$ of total world application of leather in 1990 to $53.3 \%$ in 2010), especially due to the growth in the automotive and upholstery (and furniture) industries. In the Italian context, footwear is still the most important use of finished leather, but it is less relevant than at the global level. Italy has observed the same trends national as have been seen globally: the usage of leather in footwear decreased, while automotive and leather goods increased.

Within these industries, global lead firms play a key role (e.g., IKEA in the upholstery and furniture industry, LVMH and Kering group in the fashion industry, Audi and BMW in the automotive industry), especially global buyers, who are central actors in the GVC analysis, being large multinationals with strong branding, marketing, and design capabilities. Despite not producing the products sold under their brand directly (if not a tiny fraction of them), lead firms decide what is produced where and set the standards (from an environmental, social, and economic point of view) that suppliers manufacturing components or final products have to obey. The case of the Zero Discharge of Hazardous Chemicals 
(ZDHC) program (https://www.roadmaptozero.com) is an example of how lead firms might support a move toward greener solutions in the leather industry. To clarify what is meant by "global buyer," Table 2 reports some of the major lead firms in the most relevant sectors that use finished leather as an input for the global and European markets.

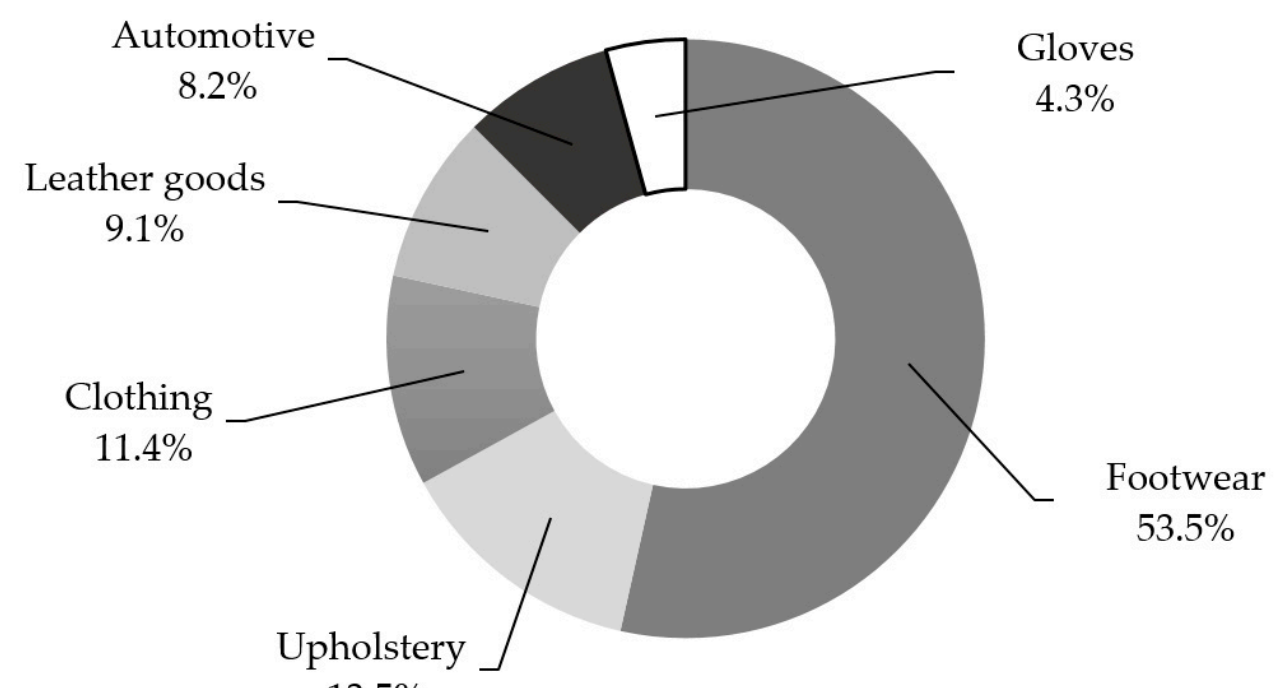

$13.5 \%$

Figure 3. Final products using leather, global shares. Source: [50].

Table 2. Global lead firms in industries applying finished leather.

\begin{tabular}{|c|c|c|c|c|}
\hline & \multicolumn{2}{|l|}{ Global } & \multicolumn{2}{|l|}{ Europe } \\
\hline & Key Companies & Country & Key Companies & Country \\
\hline \multirow{4}{*}{ Footwear } & Bata Shoes & Switzerland & Adidas AG & Germany \\
\hline & NIKE Inc. & USA & Bata Shoes & Switzerland \\
\hline & Adidas AG & Germany & Deichmann SE & Germany \\
\hline & Deichmann SE & Germany & NIKE, Inc. & USA \\
\hline \multirow{4}{*}{$\begin{array}{l}\text { Luggage and } \\
\text { leather goods }\end{array}$} & Wal-Mart Stores, Inc. & USA & Kering SA & France \\
\hline & $\begin{array}{l}\text { LVMH Moet Hennessy } \\
\text { Louis Vuitton SA }\end{array}$ & France & Marks and Spencer Group plc & UK \\
\hline & $\begin{array}{l}\text { Isetan Mitsukoshi } \\
\text { Holdings Ltd. }\end{array}$ & Japan & LVMH Moet Hennessy Louis Vuitton SA & France \\
\hline & J. C. Penney Company, Inc. & USA & Compagnie Financiere Richemont SA & Switzerland \\
\hline \multirow{4}{*}{ Automotive } & General Motors & USA & $\begin{array}{c}\text { Bayerische Motoren Werke AG } \\
\text { (BMW Group) }\end{array}$ & Germany \\
\hline & Honda & Japan & PSA Peugeot Citroen & France \\
\hline & Toyota & Japan & Renault S.A. & France \\
\hline & Volkswagen & Germany & Volkswagen & Germany \\
\hline
\end{tabular}

Source: Authors' elaboration on Marketline data (2014, 2015, 2016).

\subsubsection{Supporting Industries}

Other than the companies described, a range of supporting industries have to be considered as well, as they contribute, in some cases to a critical degree, to the development of the tannery industry. Among them, the most relevant is the chemical industry, which includes large multinationals (such as BASF), which usually provide basic inputs that are then transformed and adapted for leather production by smaller, specialized companies. They produce chemicals for beamhouse, penetrators, degreasing, emulsifying, fat liquors, auxiliary agents, and other products used in different tannery phases (see Figure 1). According to UNIC (2016) data, chemical products represent, on average, 11\% of the costs of tannery production in Italy. Such products have a key impact on the final quality (and, therefore, price) of the leather produced. 
Another supporting industry to be considered is the leather machinery production industry, realizing beamhouse, drying and finishing machinery, and other machinery needed to transform hides and skins into finished leather. At the global level, there are few companies specialized in the production of such machinery, considering the size of the market. Such companies, both large multinationals, and small companies, usually specialize in one or two machinery types. The cost of machinery represents a tiny fraction of the overall costs for tanneries.

Another industry that is supporting leather production is depuration, in the Arzignano cluster, two (public) companies provide this service to all the firms in the cluster (tanneries and chemical producers), among which the largest for the amount of water threated is Acque del Chiampo (which participates in the GreenLIFE project). According to UNIC 2016 data, the cost of water treatment represents, on average, $2.8 \%$ of the turnover of Italian tanneries. In the context of the Arzignano cluster, where there is a high concentration of tanneries, logistic companies are also present, which handle incoming hides and skins, semi-finished leather to be treated by sub-contractors, and finished leather to be shipped to customers.

\subsection{Environmental Upgrading in the Leather Value Chain: The GreenLIFE Case}

The focus of the analysis is a set of technologies developed within the GreenLIFE project. Figure 4 reports the four experimenting lines of the GreenLIFE project according to the tannery process stage they are focused on and the by-products generated by the earliest stage of the process (the grey boxes). Within the leather manufacturing process, several environmental impacts are generated. The initial step of the process (from raw hides to wet blue or white) consumes a lot of water. Chemicals are added during the process, including important pollutants, such as COD, suspended solids, chlorides, sulfates, organic nitrogen, and chromium III. Accordingly, water undergoes purification treatment to extract such pollutants from water, being finally disposed of in landfills. Indeed, several by-products are realized in this process and are usually sent to landfills, yet could still represent important secondary materials.

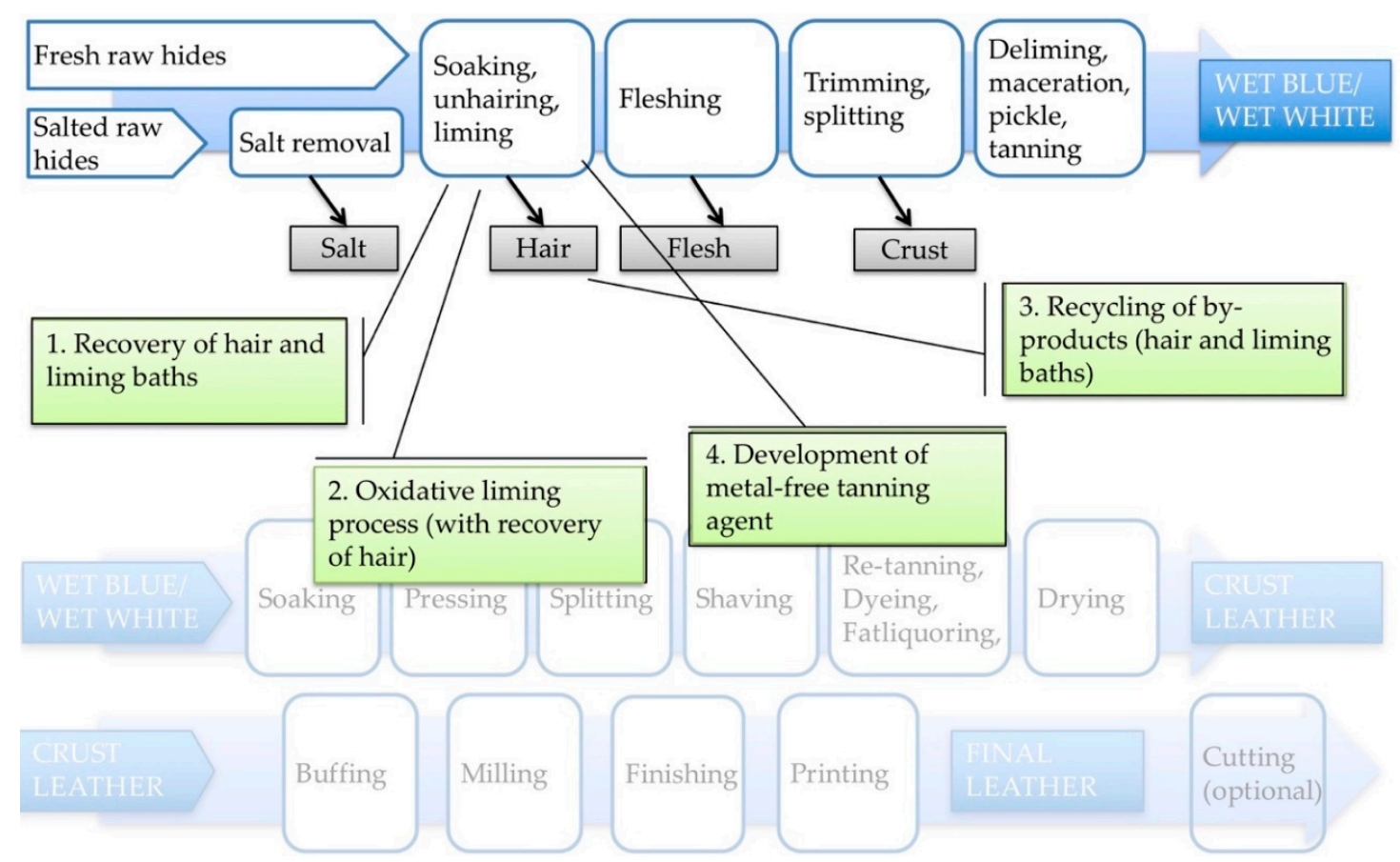

Figure 4. Environmental innovations developed within the GreenLIFE project, considering the stage of the tannery process they are impacting. Source: Authors' elaboration.

During the second stage (from wet blue or white to crust hides), water management is also a key issue, whereas in the final phase (from crust to finished leather), emissions into the atmosphere (volatile 
organic compounds and dust) are rather important. Overall, the first stage is the one with the highest concentration of environmental problems. Accordingly, the five companies operating in the Arzignano district tanning industry decided to cooperate in developing a bundle of innovations to reduce water and chemical usage, eliminate chrome from the tanning phase, and identify ways to recover and reuse process by-products (i.e., hair and flesh). In the following section, we report on the innovations developed and the environmental (and economic) outcomes they have generated. Metrics from the Life Cycle Analysis (LCA) have been used to access the outcomes of this EnvU process, which have been coupled with the qualitative information from the interviews. Important improvements regarding the social conditions of workers have also been achieved thanks to these innovations, however, these fall outside the scope of this analysis. Figure 4 summarizes the key innovations developed, mapping them against the leather production process, described in details in the following.

1. In the traditional process, several by-products are realized during the first stage of leather production, which are sent to landfills after the (costly) treatment of water. A first innovation developed within GreenLife addressed the possibility of collecting and reusing water used during the liming process, so as to collect the hair (the by-product of this process). According to the LCA analysis and tests carried out directly by the project partners, multiple figures of improvement arise. Thanks to the new process, a 70\% reduction in the use of water and $20 \%$ in sodium hydrosulphide (in beamhouse operations) were measured. According to the LCA analysis performed, the new process might allow a $6 \%$ reduction in electric energy, $12 \%$ in methane, and $24.4 \%$ in wastewater. More importantly, the new process allowed the recovery of a quantity of hair equal to $10 \%$ to $12 \%$ of the weight of the raw hides and skins used, which could be used in other applications (e.g., for the production of fertilizers).

2. Traditional liming involves the use of sulfide/sodium hydrosulphide. Within GreenLIFE projects, firms have been experimenting with a new liming process based on the use of oxygenated water, which is not a pollutant. Hair recovery (developed in the first innovation) has been implemented into this new process. The LCA analysis performed suggested that this process allows for an additional saving of $18 \%$ of water and $15 \%$ of chemicals (in the beamhouse operations). Furthermore, it reduces several pollutants: $100 \%$ in the sulfides, $32 \%$ in suspended solids, $43 \%$ in COD, and $42 \%$ in TOC (compared to the traditional process).

3. The firms have also experimented with a new process to treat the hair, one of the by-products produced by the process. The traditional process usually involves chemically dissolving the hair, which, therefore, represents an additional pollutant to treat once the water reaches the water treatment plant. A new process has been developed that uses an innovative hydrolysis technique to process the solid hair that is collected via innovations 1 and 2 and extract the keratin present in this by-product, which is suitable for use as fertilizer in farming. Additionally, a technique has been developed to collect and reuse the organic protein fraction of calcinol baths, another by-product collected from innovation 1 . Such a technique recovers $25 \%$ of solid materials (solid substances dissolved or suspended in water), mainly composed of organic material and minerals for the production of valuable solid fertilizer.

4. Finally, the firms have developed a new tanning agent from renewable sources based on natural polymers instead of chrome. Technical analysis on the environmental outcomes of this specific innovation has not yet been implemented.

\subsection{Motivations for Greening and Suppliers' Agency}

In the case described, firms have implemented an EnvU process by introducing four different, related technological innovations. They have been developed by firms in cooperation: each was spearheaded by a company, yet collaboration with other actors was also important. Each of them supported the achievement of important environmental outcomes, which promise to reduce pollution related to the leather production process significantly once fully industrialized. At the time of writing 
this article, such processes have not yet been developed at an industrial scale, but firms reported on a clear commitment in this sense. The interviews of the key actors in this process provide an understanding of the agency of the suppliers in the EnvU processes.

The CEO and the technical managers interviewed reported that the development of such innovations was motivated by an interest in improving competitiveness by gaining leadership in the green market. This analysis reflects the presence of both internal and external drivers of sustainability [1]. Internal drivers are linked to achieving efficiency benefits, resulting in a reduction in the firms' costs with respect to business-as-usual practices (i.e., reduction in the use of energy and chemical costs). More importantly, however, suppliers were driven by the strategic intent to strengthen their market position in the existing markets or enter new, profitable ones. Such firms were aware of the pressure in the final markets toward the greening of products and were subsequently motivated by an ethical perspective toward "the business of businesses." Firms reported that this effort was explicitly driven by an interest in becoming the leader in the "green leather" market.

Lead firms (especially those in the automotive industry) have been increasingly asking tanneries to reduce their environmental impacts. It is interesting to note, however, that such a costly innovation process has not yet been enacted as a result of a specific request by a lead firm. Rather, considering the perception that leads firms are going to increase their requests for environmental-related products, such suppliers proactively anticipated their request, with the aim of setting new technical standards in the industries. Indeed, the type of innovations to be implemented rather than the specific environmental outcomes they imply have not been set in collaboration with lead firms. The only exception relates to innovation 4, which has been put in place explicitly to address the lead firm's concern of buying chrome-free leather. Automotive firms are indeed interested in the possibility of burning cars at the end of their lives, and they want to avoid the presence of chrome-based leather, which, in their view, is what could reduce the overall environmental impacts related to the use of leather in cars. Lead firms, however, have not been involved in the innovation process, neither by giving technical advice, posing specific requests, nor contributing with (financial or human) resources to the process. They do not possess enough technical knowledge to contribute to such a complex innovation process.

\section{Discussion}

The GreenLIFE project demonstrates how suppliers in the GVC can propel product and process sustainability in an independent, autonomous way with respect to the role of large global buyers. Having demonstrated the ability to develop such advanced processes to meet present and future customer demand has another positive effect as it functions as a signal of the competences of the tanneries. Within the leather GVC, tanneries are usually considered merely producers, with no high value-added competences, chemical firms are developing new applications and processes (R\&D), and final product firms are handling marketing and branding activities. This project also represented an opportunity to improve the image of tanneries for clients (especially large buyers), who might now consider them capable partners for developing new product trajectories, increasing switching costs.

The most important clients (large buyers in the automotive and fashion industries) are increasingly interested in increasing the sustainability features of their products as they are subject to pressures from informed and ethical final customers and policymakers. Accordingly, they are increasingly willing to ask for input that entails environmentally friendly features. Yet, in case they do not exists already (as was the case for the leather industry), they are not strongly engaging in innovation with suppliers. It is rather the suppliers themselves who, interpreting a trend in the clients' requests for sustainability and willing to build a competitive advantage with respect to most cost-effective competitors (e.g., China), are proactively proposing new environmentally friendly products to their clients (lead firms).

Through the development of initiatives, such as the ZDHC program, lead firms have been increasingly imposing to their suppliers' boundaries for their (innovation) activities. They, however, let the suppliers bear the costs of such improvements. Within the GreenLIFE project, tanneries and their partners—in particular, the chemical company—showed their ability to design, develop, and 
implement an innovative sustainability strategy to enhance production processes and their products within an integrated approach at the cluster (value chain) level, showing the importance of considering suppliers understanding of EnvU potential. While it is not yet possible to evaluate the full economic and environmental potential of the project, as it is still in a pilot stage, preliminary results are positive, suggesting tanneries could gain internal benefits (i.e., costs reduction or competitiveness improvements).

The second important element emerging from the analysis of an EnvU process in the leather industry is the fact that environmental and economic upgrading processes cannot be understood in isolation. All the actors involved, but suppliers, in particular, are implementing environmental sustainability innovations with the aim of extracting more value within their value chain by improving their competitiveness. As for the suppliers, the new process will also improve the cost-effectiveness of leather production (especially as far as innovation lines 1 and 2 are considered) related to the reduction in the use (cost) of chemicals, water, and the like. Additionally, the new process will allow for the extraction of waste elements (hairs) that can be used in different applications, following a circular economy approach [51] (see innovation line 3). Finally, yet, more importantly, it will allow suppliers to ask clients for a premium price, given the environmentally friendly features of the new products (especially, as far as innovation 4 is concerned). The economics benefits can also be achieved by supporting industries (chemical producers and depuration) in terms of entrance into new and international markets. Similarly, lead firms will also gain the ability to ask their customers for a premium price, or they can avoid future financial costs (e.g., fines).

While all the actors benefit economically from the EnvU process, costs are not split equally. In line with some of the recent analyses on EnvU reporting the "squeeze" of suppliers [18], they emerge as the actors who are bearing the highest costs, which lead firms are not necessarily interested in subsidizing. Indeed, it is not yet clear if and to what extent lead firms will be paying a premium price for the effort of the suppliers, yet they will be interested in continuing to work with the suppliers despite the increasing international competition because such an effort will enable them to make their final products greener. It is true, however, that not all lead firms are working the same way, differences in lead firms' attitudes towards supporting suppliers exist between and within industries. Further research should investigate the circumstances that support such differential behavior.

Table 3 summarizes the economic and social impacts of all the experimenting lines, considering the different stakeholders (for the social impacts) and the value chain actors (for the economic impacts) involved.

Finally, another element that emerges from the analysis is that environmental sustainability has different meanings along the value chain for suppliers and lead firms. In particular special attention is given to chrome in the production process. Indeed, leather producers support that chrome production is the process with the lowest impacts along the chain, whereas large brands are supportive of chrome (and metal) free leather as a way to couple with the sustainability challenge (see, e.g., the ZDHC initiative). Considering the important role of large brands in influencing the development trajectories of industries, it is likely that their approach will become mainstream despite the different potential contributions that specialized suppliers—as tanneries are — can give to the innovation trajectories within the GVC. From the interviews, it emerges that the small size of suppliers-despite their expertise-is a limit with respect to other suppliers, i.e., large chemical companies that have not a deep knowledge of the leather production and convenience to develop customized solutions and products tailored on the leather industry. However, because of their larger size they become partners of lead firms (i.e., ZDHC consortium), whereas smaller specialized suppliers have not the critical mass-and institutional representation— to really influence technological and market trends.

However, as GreenLIFE demonstrates in terms of technological solutions developed, there is space for tanneries to collaborate with lead firms to develop a common view of the best technological trajectories or to propose applications for niche markets. The more tanneries become credible and representative partners in the eyes of global brands, the more likely they are to be involved in such a 
process. They will also be more likely to retain more value created through such product and process innovations. Even in this case, a cluster or industry level approach would support the achievement of this result. This is also true when considering by-products (i.e., hairs). Since waste is highly regulated at the EnvU level, it is important to ensure that such a new application would be possible, considering the Italian and EnvU rules regarding the use of industrial by-products. Again, the possibility of facing this issue at a collective (industry) level by leveraging the specialized nature of suppliers (tanneries) seems to be the most effective potential approach. From this point of view, the financial support provided by the EU through the project can be interpreted as an initial, required, mechanism, reducing risks related to innovation and further sustaining collaboration among actors. At the same time, the knowledge created enhances the experience of specialized suppliers, demonstrating the profitable (market) opportunities of such innovation trajectories.

Table 3. An overview of the economic impacts for firms belonging to the whole value chain and their location.

\begin{tabular}{|c|c|c|c|c|}
\hline & & $\begin{array}{l}\text { Suppliers } \\
\text { (Tanneries) }\end{array}$ & $\begin{array}{l}\text { Supporting Industries } \\
\text { (Chemical Companies) }\end{array}$ & $\begin{array}{c}\text { Buyers (Fashion or } \\
\text { Automotive Companies) }\end{array}$ \\
\hline $\begin{array}{l}\text { Economic } \\
\text { benefits }\end{array}$ & $\begin{array}{l}\text { Improved products } \\
\text { Strengthening market position } \\
\text { Improved visibility to clients } \\
\text { Better control of production } \\
\text { activities } \\
\text { Speed in the production process } \\
\text { Chemical costs reduction } \\
\text { Water costs reduction } \\
\text { Other production costs reduction } \\
\text { Deputation/by-product } \\
\text { related-cost reduction } \\
\text { Reduced costs for end-of-life } \\
\text { treatment }\end{array}$ & & & \\
\hline $\begin{array}{l}\text { Economic } \\
\text { costs }\end{array}$ & $\begin{array}{c}\text { Investments in new equipment } \\
\text { Investments in training } \\
\text { Costs for recovery, storing and } \\
\text { treating by-products } \\
\text { Higher costs for chemicals } \\
\text { Reducing the role of existing } \\
\text { product }\end{array}$ & & & \\
\hline
\end{tabular}

Note: Grey areas signal which firms are connected to each economic impact element. Source: Author.

\section{Conclusions}

The paper provides evidence of EnvU processes put in place by suppliers within the leather GVC, highlighting the bottom-up dynamics implemented. With respect to GVC studies on environmental upgrading that stress the relevance of lead firms in driving sustainability, our study further advances the theory of how EnvU can occur and its role in suppliers' agency. Indeed, suppliers might have a proactive strategy toward sustainability and become actors that propose new technological advances that can support an effective reduction of environmental impacts. In line with results present in management literature $[17,52]$, the results described in this paper suggest that suppliers can be moved toward sustainability because of internal drivers (related to competitiveness) rather than external (related to specific lead firm requests). Given their technological expertise and interest in developing new forms of competitiveness, suppliers might indeed be the protagonists of EnvU, in line with the economic upgrading dynamics suggested by [8], by enabling lead firms to be greener. This evidence supports the recent contributions that stress the importance of going beyond the top-down approach in order to grasp the rationale for firms to embrace sustainability and the opportunities for their effort to spread along the GVC $[7,18]$. While many of those studies, however, have focused on developing countries, the empirical setting chosen-capable suppliers based in a developed country-testifies to a broader autonomy of suppliers. 
This is not to say, however, that lead firms do not play a key role in this context. The power between suppliers and lead firms is definitely unbalanced, and they bind suppliers' activities, sometimes in terms of the technological trajectories pursued (e.g., see the discussion on chrome-free leather). However, they do not take any "hands-on" mechanisms [6], and-a point that deserves future critical investigation-do not take on any costs of the EnvU pursued by suppliers, despite what firms gain from the outcome of such efforts, in line with what is suggested in $[18,53]$. However, reducing EnvU to a top-down approach initiated by a lead firm would be misleading. Mimicking the terminology adopted by [54] to describe power in GVCs, we could say that our results reflect the importance of adopting a multipolarity approach to EnvU, which allows the disclosure of the agency of the actors that engaged in the GVC, each with different motives to go green, different understandings of what green is, and different competences to pursue that direction.

While providing interesting insights, this analysis is exploratory in nature. Further research should address similar issues, considering different industries and empirical contexts so as to appreciate the conditions under which the dynamics emerging from this case can be generalized. Furthermore, considering for the fact that sustainability is "a moving target," it would be interesting to follow up over the next few years to verify if and how the EnvU effort of the firms involved has impacted the power and governance in their GVC (this was indeed an outcome of EnvU in other studies [6]). Finally, we believe further analysis should be conducted to investigate the aspect of (environmental) value appropriation in GVCs critically, i.e., to assess the extent to which suppliers can gain higher margins because of the EnvU process they (autonomously) enact.

Author Contributions: Conceptualization, V.D.M. and E.D.M.; methodology, V.D.M.; investigation, V.D.M. and E.D.M.; data curation, V.D.M.; writing—original draft preparation, E.D.M.; writing—review and editing, V.D.M.; project administration, E.D.M.; funding acquisition, V.D.M.

Funding: This research was funded by the European Union-LIFE Programme-Project: Green Leather Industry for the Environment, grant number: LIFE13 ENV/IT/000840.

Acknowledgments: The authors want to acknowledge support from the coordinator of the GreenLIFE project (Dani) in facilitating data collection, and in particular the support by Guido Zilli. The authors also thank all the experts, managers, and technicians belonging to the other organizations that participated in the research. Usual disclaimers apply.

Conflicts of Interest: The authors declare no conflict of interest.

\section{References}

1. Lozano, R. A holistic perspective on corporate sustainability drivers. Corp. Soc. Responsib. Environ. Manag. 2015, 22, 32-44. [CrossRef]

2. De Marchi, V. Environmental innovation and R\&D cooperation: Empirical evidence from Spanish manufacturing firms. Res. Policy 2012, 41, 614-623.

3. Niesten, E.; Jolink, A.; Lopes de Sousa Jabbour, A.B.; Chappin, M.; Lozano, R. Sustainable collaboration: The impact of governance and institutions on sustainable performance. J. Clean. Prod. 2017, 155, 1-6. [CrossRef]

4. Poulsen, R.T.; Ponte, S.; Sornn-Friese, H. Environmental upgrading in global value chains: The potential and limitations of ports in the greening of maritime transport. Geoforum 2018, 89, 83-95. [CrossRef]

5. De Marchi, V.; Di Maria, E.; Krishnan, A.; Ponte, S. Environmental upgrading in global value chains. In Handbook on Global Value Chains; Ponte, S., Gereffi, G., Raj-Reichert, G., Eds.; Edward Elgar Publishing: Cheltenham, UK, 2019; pp. 310-323.

6. De Marchi, V.; Di Maria, E.; Ponte, S. The greening of global value chains: Insights from the furniture industry. Compet. Chang. 2013, 17, 299-318. [CrossRef]

7. Krishnan, A. Re-thinking the environmental dimensions of upgrading and embeddedness in production networks: The case of Kenyan horticulture farmers. Ph.D. Dissertation, University of Manchester, Manchester, UK, 2017.

8. Sako, M.; Zylberberg, E. Supplier strategy in global value chains: Shaping governance and profiting from upgrading. Socio-Economic Rev. 2017, 17, 687-707. [CrossRef] 
9. Nadvi, K.; Raj-Reichert, G. Governing health and safety at lower tiers of the computer industry global value chain. Regul. Gov. 2015, 9, 243-258. [CrossRef]

10. Giuliani, E.; de Marchi, V.; Rabellotti, R. Do Global Value Chains Offer Developing Countries Learning and Innovation Opportunities? Eur. J. Dev. Res. 2017, 30, 389-407.

11. Carswell, G.; De Neve, G. Labouring for global markets: Conceptualising labour agency in global production networks. Geoforum 2013, 44, 62-70. [CrossRef]

12. Krauss, J.; Krishnan, A. Global Decisions and Local Realities: Priorities and Producers' Upgrading Opportunities in Agricultural Global Production Networks. UNFSS Discussion paper no. 7. 2016.

13. Gereffi, G. Global value chains in a post-Washington Consensus world. Rev. Int. Polit. Econ. 2014, $21,9-37$. [CrossRef]

14. De Marchi, V.; Di Maria, E.; Ponte, S. Multinational firms and the management of global networks: Insights from global value chain studies. In Orchestration of the Global Network Organization; Emerald: Bingley, UK, 2014; Volume 27, pp. 463-486. ISBN 1571-5027.

15. Gereffi, G.; Fernandez-Stark, K. Global Value Chain Analysis: A Primer; Duke Center on Globalizatgion, Governance and Competitiveness: Durham, NC, USA, 2016.

16. Khattak, A.; Pinto, L. A systematic literature review of the environmental upgrading in global value chains and future research agenda. J. Distrib. Sci. 2018, 16, 11-19. [CrossRef]

17. De Marchi, V.; Di Maria, E.; Micelli, S. Environmental Strategies, Upgrading and Competitive Advantage in Global Value Chains. Bus. Strateg. Environ. 2013, 22, 62-72. [CrossRef]

18. Ponte, S. Business, Power and Sustainability in a World of Global Value Chains; Zed Books: London, UK, 2019.

19. Boons, F. Greening products: A framework for product chain management. J. Clean. Prod. 2002, 10, 495-505. [CrossRef]

20. Webster, K.; MacArthur, E. The Circular Economy: A Wealth of Flows, 2nd ed.; EllenMacArthur Foundation Publishing: Cowes, UK, 2017.

21. Liu, S.; Kasturiratne, D.; Moizer, J. A hub-and-spoke model for multi-dimensional integration of green marketing and sustainable supply chain management. Ind. Mark. Manag. 2012, 41, 581-588. [CrossRef]

22. Cainelli, G.; Mazzanti, M.; Zoboli, R. Environmentally oriented innovative strategies and firm performance in services. Micro-evidence from Italy. Int. Rev. Appl. Econ. 2011, 25, 61-85. [CrossRef]

23. Cainelli, G.; De Marchi, V.; Grandinetti, R. Does the development of environmental innovation require different resources? Evidence from Spanish manufacturing firms. J. Clean. Prod. 2015, 94, 211-220. [CrossRef]

24. Chen, Y.S.; Lin, Y.H.; Lin, C.Y.; Chang, C.W. Enhancing green absorptive capacity, green dynamic capacities and green service innovation to improve firm performance: An analysis of Structural Equation Modeling (SEM). Sustainability 2015, 7, 15674-15692. [CrossRef]

25. Albort-Morant, G.; Leal-Rodríguez, A.L.; De Marchi, V. Absorptive capacity and relationship learning mechanisms as complementary drivers of green innovation performance. J. Knowl. Manag. 2018, 22, 432-452. [CrossRef]

26. Geffen, C.A.; Rothenberg, S. Suppliers and environmental innovation. Int. J. Oper. Prod. Manag. 2000, 20, 166-186. [CrossRef]

27. Rennings, K. Redefining innovation-Eco-innovation research and the contribution from ecological economics. Ecol. Econ. 2000, 32, 319-332. [CrossRef]

28. Nikolakis, W.; John, L.; Krishnan, H. How blockchain can shape sustainable global value chains: An Evidence, Verifiability, and Enforceability (EVE) Framework. Sustainability 2018, 10, 3926. [CrossRef]

29. Lopes de Sousa Jabbour, A.B.; Jabbour, C.J.C.; Godinho Filho, M.; Roubaud, D. Industry 4.0 and the circular economy: A proposed research agenda and original roadmap for sustainable operations. Ann. Oper. Res. 2018, 270, 273-286. [CrossRef]

30. Jaffe, A.B.; Newell, R.G.; Stavins, R.N. A tale of two market failures: Technology and environmental policy. Ecol. Econ. 2005, 54, 164-174. [CrossRef]

31. Devinney, T.M.; Auger, P.; Eckhardt, G.M. The Myth of the Ethical Consumer; Cambridge University Press: New York, NY, USA, 2010; ISBN 9780802094674.

32. Bush, S.R.; Oosterveer, P.; Bailey, M.; Mol, A.P.J.J. Sustainability governance of chains and networks: A review and future outlook. J. Clean. Prod. 2015, 107, 8-19. [CrossRef]

33. Lee, J.; Gereffi, G. Global value chains, rising power firms and economic and social upgrading. Crit. Perspect. Int. Bus. 2015, 11, 319-339. [CrossRef] 
34. Ponte, S.; Ewert, J. Which Way is "Up" in Upgrading? Trajectories of Change in the Value Chain for South African Wine. World Dev. 2009, 37, 1637-1650. [CrossRef]

35. Choksy, U.S.; Sinkovics, N.; Sinkovics, R.R. Exploring the relationship between upgrading and capturing profits from GVC participation for disadvantaged suppliers in developing countries. Can. J. Adm. Sci. 2017, 34, 356-386. [CrossRef]

36. Van Biesebroeck, J.; Sturgeon, T.J. Effects of the 2008-09 crisis on the automotive industry in developing countries: A global value chain perspective. In Global Value Chains in a Postcrisis World; Cattaneo, O., Gereffi, G., Staritz, C., Eds.; World Bank Publications: Washington, DC, USA, 2010.

37. Azmeh, S.; Nadvi, K. Asian firms and the restructuring of global value chains. Int. Bus. Rev. 2014, 23, 708-717. [CrossRef]

38. Blackman, A. Informal sector pollution control: What policy options do we have? World Dev. 2000, 28, 2067-2082. [CrossRef]

39. Randelli, F.; Lombardi, M. The Role of Leading Firms in the Evolution of SME Clusters: Evidence from the Leather Products Cluster in Florence. Eur. Plan. Stud. 2014, 22, 1199-1211. [CrossRef]

40. Tewari, M.; Pillai, P. Global standards and the dynamics of environmental compliance in India's leather industry. Oxford Dev. Stud. 2005, 33, 245-267. [CrossRef]

41. FAO. World Statistical Compendium for Raw Hides and Skins, Leather and Leather Footwear 1999-2015; Food and Agriculture Organization of the United States (FAO): Rome, Italy, 2016.

42. UNIC. Relazione Del Presidente; Unione Nazionale Industria Conciaria (UNIC): Rome, Italy, 2016.

43. Belussi, F. The international resilience of Italian industrial districts/clusters (ID/C) between knowledge-re-shoring and manufacturing off (near)-shoring. J. Reg. Res. 2015, 32, 89-113.

44. Belussi, F.; Sedita, S.R. L'evoluzione del modello distrettuale: La" delocalizzazione inversa" e il caso del distretto della concia di Arzignano. Econ. e Polit. Ind. 2008, 2, 51-72.

45. Da Ronch, B.; Di Maria, E.; Micelli, S. Clusters Go Green: Drivers of environmental sustainability in local networks of SMEs. Int. J. Inf. Syst. Soc. Chang. 2013, 4, 37-52. [CrossRef]

46. Yin, R. Case Study Research: Design and Methods; Applied Social Research Methods; SAGE Publications: Thousand Oaks, CA, USA, 2009; ISBN 9781412960991.

47. UNIC. Rapporto di sostenibilità; Unione Nazionale Industria Conciaria (UNIC): Rome, Italy, 2016.

48. COTANCE. Social and Environmental Report. the European leather industry; European Confederation of the Leather Industry (COTANCE): Brussels, Belgium, 2012.

49. Frederick, S. Global value chain mapping. In Handbook on Global Value Chains; Ponte, S., Gereffi, G., Raj-Reichert, G., Eds.; Edward Elgar: Cheltenham, UK, 2019; pp. $29-53$.

50. UNIDO. Future trends in the World Leather and Leather Products Industry and Trade; United Nations Industrial development Organization (UNIDO): Wien, Austria, 2010.

51. Ghisellini, P.; Cialani, C.; Ulgiati, S. A review on circular economy: The expected transition to a balanced interplay of environmental and economic systems. J. Clean. Prod. 2016, 114, 11-32. [CrossRef]

52. Orsato, R.J. Competitive Environmental Strategies. Calif. Manag. Rev. 2006, 48, 127-143.

53. Giuliani, E. Why multinational enterprises may be causing more inequality than we think. Multinatl. Bus. Rev. 2019, 27, 221-225. [CrossRef]

54. Dallas, M.P.; Ponte, S.; Sturgeon, T.J. Power in global value chains. Rev. Int. Polit. Econ. 2019, 26, 666-694. [CrossRef]

(C) 2019 by the authors. Licensee MDPI, Basel, Switzerland. This article is an open access article distributed under the terms and conditions of the Creative Commons Attribution (CC BY) license (http://creativecommons.org/licenses/by/4.0/). 